\title{
Simultaneous a-amylase and protease production by the soil bacterium Bacillus sp. SMIA-2 under submerged culture using whey protein concentrate and corn steep liquor: compatibility of enzymes with commercial detergents
}

\author{
Produção simultânea de $\alpha$-amilase e protease pela bactéria do solo Bacillus sp. SMIA-2 em \\ culturas submersas utilizando concentrado de proteínas do soro e água de maceração de milho: \\ compatibilidade das enzimas com detergentes comerciais
}

Thamy Lívia Ribeiro CORRÊA ${ }^{1}$, Stella Karla dos Santos MOUTINHO', Meire Lelis Leal MARTINS ${ }^{1 \star}$, Marco Antônio MARTINS ${ }^{1}$

\begin{abstract}
Protease and $\alpha$-amylase production by a thermophilic Bacillus sp. SMIA-2 cultivated in liquid cultures containing $0.25 \%$ (w/v) starch as a carbon

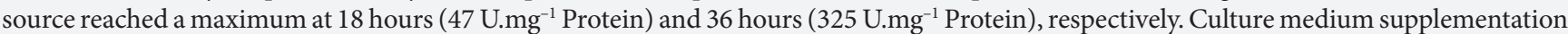
with whey protein concentrate $(0.1 \%, \mathrm{w} / \mathrm{v})$ and corn steep liquor $(0.3 \%, \mathrm{w} / \mathrm{v})$ not only improved the production of both enzymes but also enabled them to be produced simultaneously. Under these conditions, $\alpha$-amylase and protease production reached a maximum in 18 hours with levels of $401 \mathrm{U}_{\mathrm{mg}}{ }^{-1}$ protein and $78 \mathrm{U} \cdot \mathrm{mg}^{-1}$ protein, respectively. The compatibility of the enzymes produced with commercial laundry detergent was investigated. In the presence of Campeiro ${ }^{\circ}$ detergent, $\alpha$-amylase activity increased while protease activity decreased by about $27 \%$. These enzymes improved the cleaning power of Campeiro detergent since they were able to remove egg yolk and tomato sauce stains when used in this detergent.

Keywords: proteases; $\alpha$-amylase; thermophilic bacterium; Bacillus sp.; detergents.
\end{abstract}

\section{Resumo}

A produção de proteases e $\alpha$-amilase pelo termofílico Bacillus sp. cepa SMIA-2 cultivado em culturas líquidas contendo 0,25\% (w/v) de amido como fonte de carbono alcançou o máximo em 18 horas (47 U.mg ${ }^{-1}$ Proteína) e 36 horas (325 U.mg-1 Proteína), respectivamente. A suplementação do meio de cultura com proteínas do soro de leite $(0,1 \%$, w/v) e água de maceração de milho $(0,3 \%$, w/v) não apenas aumentou a atividade de ambas as enzimas como tornou possível a produção simultânea das mesmas. Nestas condições, as maiores atividades da

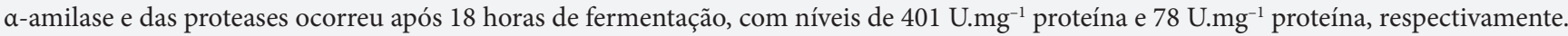
A compatibilidade das enzimas produzidas com detergentes comerciais foi investigada. Na presença do detergente Campeiro a atividade da $\alpha$-amilase aumentou, enquanto a atividade da protease decresceu em torno de $27 \%$. Estas enzimas melhoraram o poder de lavagem do detergente Campeiro ${ }^{\circ}$. Elas removeram manchas de gema de ovo e de molho de tomate, quando utilizadas juntas com este detergente.

Palavras-chave: proteases; $\alpha$-amilase; bactéria termofílica; Bacillus sp.; detergentes.

\section{Introduction}

Amylases and proteases are among the most valuable commercial enzymes (GHORBEL; SELLAMI-KAMOUN; NASRI, 2003; OLIVEIRA et al., 2006; MERHEB et al., 2007; MUSSATO; FERNANDES; MILAGRES, 2007; HMIDET et al., 2008; KIRAN; CHANDRA, 2008) and are used in a variety of industrial applications such as pharmaceutical agents, food products, and laundry detergents (GUPTA et al., 2003; HADJALI et al., 2007; SELLAMI-KAMOUN et al., 2008; KIRAN; CHANDRA, 2008).

Although amylases and proteases can be derived from several sources, including plants, animals, and microorganisms, microbial enzymes generally meet industrial demands (JOHNVESLY; NAIK, 2001; van DER MAAREL et al., 2002; AQUINO et al., 2003). Bacteria belonging to Bacillus sp. produce a large variety of extracellular enzymes, of which amylases and proteases are of significant industrial importance (RAO et al., 1998; SCHALLMEY; SINGH; WARD, 2004; SAJEDI et al., 2005; SELLAMI-KAMOUN et al., 2008). The amylases and proteases produced by different species of Bacillus vary not only in type but also in $\mathrm{pH}$ and optimum temperature, in addition to being capable of functioning at high temperatures and $\mathrm{pH}$ values (NIELSEN; BORCHERT, 2000; GUPTA et al., 2003). They are, therefore, attractive for use in detergent formulations. Proteases are the first enzyme class used in the formulation of enzymatic detergent, and amylases are the second type of enzymes used (MITIDIERI et al., 2006).

Currently, one of the major bottlenecks facing industrial enzyme producers is the high cost of enzyme production. It is

Received 30/4/2009

Accepted 15/11/2010 (004182)

Centro de Ciências e Tecnologias Agropecuárias, Universidade Estadual do Norte Fluminense Darcy Ribeiro - UENF, Av. Alberto Lamego, 2000, CEP 28015-620,

Campos dos Goytacazes, RJ, Brazil, e-mail: meire@uenf.br

${ }^{*}$ Corresponding author 
estimated that around $30-40 \%$ of the production cost of many industrial enzymes is attributable to the cost of the growth substrate (JOO; CHANG, 2005). The use of low-cost growth substrates for industrial enzyme production is expected to reduce production costs drastically. Agro-industrial byproducts, such as those derived from corn and the dairy industry, could serve as inexpensive fermentation sources (PELIZER; PONTIERI; MORAES, 2007; CARVALHO et al., 2008). In addition, production of more than one enzyme in one step significantly increases the efficiency and improves the economy of the process. This is especially important for proteases and amylases, which account for over 60 and $25 \%$ of the total industrial enzyme market, respectively (MERHEB et al., 2007; van DER MAAREL et al., 2002; ABIDI; LIMAN; NEGIB, 2008; KIRAN; CHANDRA, 2008).

The preliminary conditions for using enzymes as a detergent additive are not only the production level of the enzyme but also its compatibility and stability in various detergents. This paper reports on the simultaneous production of protease and amylase enzymes by thermophilic Bacillus sp. SMIA-2 in an economic medium and the efficacy of the enzymes in the presence of standard commercial detergents.

\section{Material and methods}

\subsection{Microorganism and culture conditions}

The microorganism used in the present study was Bacillus sp. SMIA-2, a thermophilic strain previously isolated from a local soil sample (SOUZA; MARTINS, 2001).

Production of $\alpha$-amylase and protease was carried out in a medium containing (g. $\mathrm{L}^{-1}$ of distilled water): $\mathrm{KCl}$ $0.3, \mathrm{MgSO}_{4}-0.5, \mathrm{~K}_{2} \mathrm{HPO}_{4}-0.87, \mathrm{CaCl}_{2}-2.2 \times 10^{-3}, \mathrm{ZnO}-$ $2.5 \times 10^{-3}, \mathrm{FeCl}_{3} \cdot 6 \mathrm{H}_{2} \mathrm{O}-2.7 \times 10^{-2}, \mathrm{MnCl}_{2} \cdot 4 \mathrm{H}_{2} \mathrm{O}-1.0 \times 10^{-2}$ $\mathrm{CuCl}_{2} .2 \mathrm{H}_{2} \mathrm{O}-8.5 \times 10^{-4}, \mathrm{CoCl}_{2} \cdot 6 \mathrm{H}_{2} \mathrm{O}-2.4 \times 10^{-3}$, $\mathrm{NiCl}_{3} \cdot 6 \mathrm{H}_{2} \mathrm{O}-2.5 \times 10^{-4}, \mathrm{H}_{3} \mathrm{BO}_{3}-3.0 \times 10^{-4}$, peptone-1.0, soluble starch-2.5, whey protein concentrate-0.1, and corn steep liquor-0.3. The $\mathrm{pH}$ was adjusted to 7.5 with $\mathrm{NaOH}$ and this basal medium was sterilized by autoclaving at $121{ }^{\circ} \mathrm{C}$ for 15 minutes. The medium $(25 \mathrm{~mL}$ in $250 \mathrm{~mL}$ Erlenmeyer flasks) was inoculated with $1 \mathrm{~mL}$ of an overnight culture and incubated at $50{ }^{\circ} \mathrm{C}$ in an orbital shaker (TECNAL TE$420)$ at $150 \mathrm{rpm}$. Triplicate flasks were withdrawn at regular intervals, and the turbidity of the cultures was determined by measuring the increase in optical density at $600 \mathrm{~nm}$ using a UV-mini 1240 spectrophotometer from SHIMADZU. Before the assay, the cells were separated by centrifugation at $1020 \mathrm{~g}$ (centrifugal HERMLE-Z 382) for 15 minutes at $4{ }^{\circ} \mathrm{C}$, and the clear supernatant was used as the crude enzyme preparation.

\subsection{Enzymes assay}

The activity of $\alpha$-amylase was assayed in triplicate by incubating $0.5 \mathrm{~mL}$ of the enzyme with $0.5 \mathrm{~mL}$ soluble starch $(0.5 \%, \mathrm{w} / \mathrm{v})$ prepared in $0.05 \mathrm{M}$ Tris- $\mathrm{HCl}$ buffer, $\mathrm{pH}$ 8.5. After incubation at $90^{\circ} \mathrm{C}$ for 10 minutes, the reaction was stopped and the reducing sugars released were assayed colorimetrically by the DNSA method (MILLER, 1959). One enzyme activity Unit (U) was defined as the amount of enzyme releasing $1 \mu \mathrm{mol}$ of glucose from the substrate in 1 minute under the assay conditions.

Protease activity was assessed in triplicate by measuring the release of trichloroacetic acid soluble peptides from $0.2 \%$ $(\mathrm{w} / \mathrm{v})$ azocasein in $0.1 \mathrm{M}$ Tris- $\mathrm{HCl}$ buffer, $\mathrm{pH} 8.5$ at $70^{\circ} \mathrm{C}$ for 10 minutes. The $1 \mathrm{~mL}$ reaction was terminated by the addition of $0.5 \mathrm{~mL}$ of $15 \%$ trichloroacetic acid and then centrifuged at $11340 \mathrm{~g}$ for 10 minutes, after cooling. One enzyme activity Unit $(\mathrm{U})$ was defined as the amount of enzyme required to produce an increase in absorbance at $420 \mathrm{~nm}$ equal to 0.1 in 60 minutes (JANSSEN; PEEK; MORGAN, 1994).

Protein was measured by the Petterson method (1977).

\subsection{Evaluation of enzymes for use in detergent formulations}

The detergent brands used were Ariel ${ }^{\circ}, \mathrm{Biz}^{\oplus}$, Cheer ${ }^{\oplus}$, Tide ${ }^{\circ}$, Campeiro ${ }^{\circ}$, and $\mathrm{Omo}^{\circ}$. They were diluted in distilled water to a final concentration of $7 \mathrm{mg} \cdot \mathrm{mL}^{-1}$ to simulate washing conditions and were heated to $100^{\circ} \mathrm{C}$ for 15 minutes to inactivate the enzymes that could be part of their formulations. Next, the detergents were introduced into the reaction mixture, and the reaction was carried out under standard assay conditions (PHADATARE; DESHPANDE; SRINIVASAN, 1993; BANERJEE et al., 1999). The activity of the crude enzyme assayed in the absence of detergents was taken as $100 \%$.

The application of enzymes as a detergent additive was studied on pieces of white cotton cloth $(5 \times 5 \mathrm{~cm})$ stained with egg yolk (rich in protein) and tomato sauce (rich in starch). The stained cloth pieces were placed in separate flasks. The following sets were prepared:

Flask with distilled water $(100 \mathrm{~mL})$;

Flask with distilled water $(100 \mathrm{~mL})+1 \mathrm{~mL}$ detergent (7 mg.mL $\left.{ }^{-1}\right)$;

Flask with distilled water $(100 \mathrm{~mL})+1 \mathrm{~mL}$ detergent (7 mg. $\left.\mathrm{mL}^{-1}\right)+2 \mathrm{~mL}$ enzyme solution;

Flask with distilled water $(100 \mathrm{~mL})+1 \mathrm{~mL}$ detergent (7 mg. $\left.\mathrm{mL}^{-1}\right)+5 \mathrm{~mL}$ enzyme solution.

The above flasks were incubated at $50{ }^{\circ} \mathrm{C}$ for 15 minutes. After incubation, the pieces of cloth were taken out, rinsed with water, and dried. Visual examination of various pieces exhibited the effect of the enzyme on stain removal. Untreated pieces of cloth stained with yolk egg and tomato sauce were taken as control (BANERJEE et al., 1999; ABIDI; LIMAN; NEGIB, 2008).

\section{Results and discussion}

\subsection{Enzymatic production}

Profiles of the cell growth, medium $\mathrm{pH}, \boldsymbol{\alpha}$-amylase, and protease activity of Bacillus sp. strain SMIA-2 cultivated in a basal medium containing soluble starch $(0.25 \% \mathrm{w} / \mathrm{v})$ as a carbon source are shown in Figure 1. It can be seen that protease production reached a maximum at 12 hours, with levels of $47 \mathrm{U} . \mathrm{mg}^{-1}$ protein. Subsequently, protease levels remained more or less constant up to 18 hours and then began to fall. 


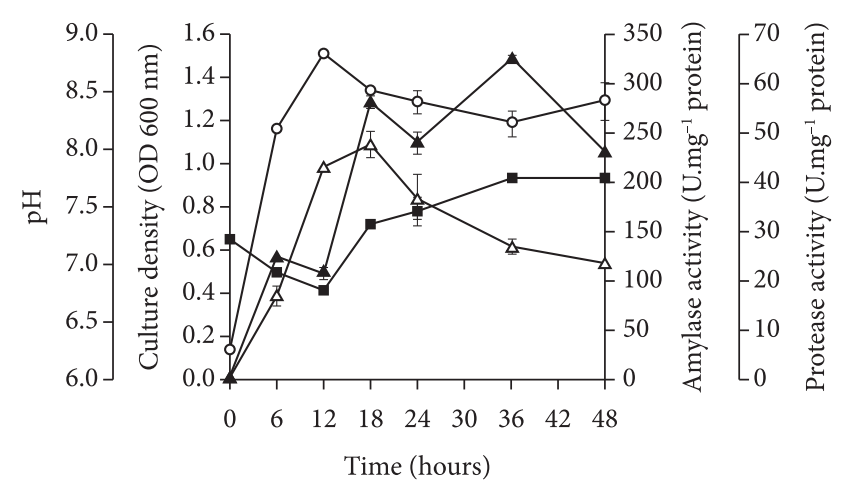

$\circ \mathrm{DO}_{600 \mathrm{~nm}}-\mathrm{pH} \Delta$ Amylase activity $\Delta$ Protease activity

Figure 1. Time course of protease and $\alpha$-amylase production by Bacillus sp. strain SMIA-2 grown at $50{ }^{\circ} \mathrm{C}$ on soluble starch $(0.25 \%$ $\mathrm{w} / \mathrm{v})$ in shake flasks. Results represent the means of three separate experiments, and bars indicate \pm 1 standard deviation. Absence of bars indicates that errors were smaller than symbols. $\mathrm{DO}_{600 \mathrm{~nm}}(\mathrm{O}) ; \mathrm{pH}$ $(\boldsymbol{\bullet})$; Amylase activity $(\Delta)$; Protease activity $(\boldsymbol{\Delta})$.

This suggests that protease production was directly linked to the culture being metabolically active. According to Ming Chu, Lee and $\mathrm{Li}$ (1992), protease production is characterized by an abrupt decrease in enzyme activity in the late exponential phase of a batch culture.

The production of a-amylase by Bacillus sp. strain SMIA-2 began during the exponential growth phase, reaching a maximum at 36 hours with levels of $325 \mathrm{U}_{\mathrm{mg}}^{-1}$ protein. Subsequently, the amylase levels dropped to $230 \mathrm{U} \cdot \mathrm{mg}^{-1}$ at 48 hours. These results suggest that effective $\alpha$-amylase induction did not occur until the readily available carbon source was depleted.

The medium $\mathrm{pH}$ declined from 7.22 to 6.77 within 12 hours, which seems to be the end of the exponential growth and started to rise again until it reached 7.76. This decline in the medium $\mathrm{pH}$ during the exponential growth phase might be due to the production of acid by the use of glucose derived from starch (JOO; CHANG, 2005), and the rise in $\mathrm{pH}$ could be attributed to the consumption of organic acids. This profile of $\mathrm{pH}$ change is a good indicator for monitoring enzyme production during fermentation.

A successful and significant improvement (1.5-fold) in protease and amylase production by Bacillus sp. SMIA-2 was obtained when the culture medium was supplemented with $0.1 \%(\mathrm{w} / \mathrm{v})$ Whey Protein Concentrate (WPC) in addition to $0.3 \%(w / v)$ Corn Steep Liquor (CSL) (Figure 2). The levels of activity found were comparable with those reported when either of these enzymes was produced alone (NASCIMENTO; MARTINS, 2004; CARVALHO et al., 2008). In addition, the optimum activities of both enzymes were obtained under the same conditions as far as time (18 hours) was concerned. This synchronization is important because it simplifies simultaneous production control.

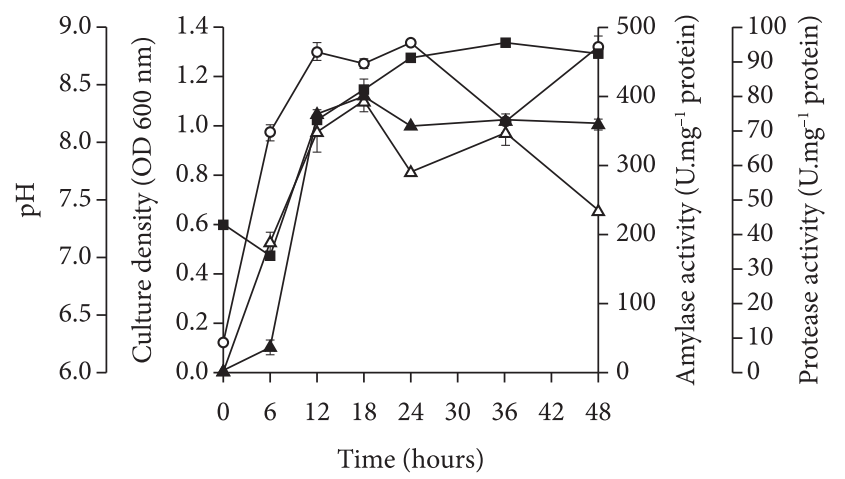

$\circ \mathrm{DO}_{600 \mathrm{~nm}}$ - $\mathrm{pH} \Delta$ Amylase activity $\Delta$ Protease activity

Figure 2. Time course of protease and $\alpha$-amylase production by Bacillus sp. strain SMIA-2 grown at $50{ }^{\circ} \mathrm{C}$ on soluble starch $(0.25 \%$ $\mathrm{w} / \mathrm{v})$, whey protein concentrate $(0.1 \% \mathrm{w} / \mathrm{v})$, and corn steep liquor $(0.3 \%$ $\mathrm{w} / \mathrm{v})$ in shake flasks. Results represent the means of three separate experiments, and bars indicate standard deviation. Absence of bars indicates that errors were smaller than symbols. $\mathrm{DO}_{600 \mathrm{~nm}}(\mathrm{O})$; $\mathrm{pH}(\mathbf{-})$; Amylase activity $(\Delta)$; Protease activity $(\boldsymbol{\Delta})$.

The medium $\mathrm{pH}$ declined from 7.27 to 7.01 within 6 hours and thereafter started to rise again until it reached 8.78 .

It has been shown that enhanced amylase and protease production was achieved for other strains including Bacillus species when increasing the availability of nitrogen in the medium, generally by means of yeast extract and/or peptone addition (SAXENA et al., 2007; MUKHERJEE; ADHIKARI; RAI, 2008). In the present experiment, supplementation with WPC and CSL provided an additional nitrogen source by providing peptides, and the amino acids were readily available for cell metabolism and showed an increase in protease and a-amylase production. Therefore, the co-utilization of WPC and CSL is an attractive choice for protease and $\alpha$-amylase production by Bacillus sp. SMIA-2 since both are good sources of nutrients and important metal ions (RIVAS et al., 2004; DIAS et al., 2008) in addition to being inexpensive. Thus, the simple expedient of supplementing the medium with WPC and CSL would result in reducing the production costs of protease and amylase produced by Bacillus sp. SMIA-2.

\subsection{Evaluation of enzyme for use in detergent formulation}

Studies on the effect of detergents on enzyme activities (Figure 3 ) show that $\alpha$-amylase activity increased in the presence of Campeiro and decreased about 12,22, and 30\% in the presence of the detergents $\mathrm{Omo}^{\circledR}, \mathrm{Biz}^{\oplus}$, and Cheer ${ }^{\oplus}$. The protease activity decreased by about 27 and $50 \%$ in the presence of Campeiro and Tide detergents, respectively. These results suggest that the performance of the enzymes in detergents depends on a number of factors including the detergent compounds since the enzyme activities varied with each laundry detergent.

The compatibility of the protease and a-amylase coproduced by Bacillus licheniformis $\mathrm{NH} 1$ with laundry detergents was investigated by Hmidet et al. (2009). According to these 
authors, NH1 a-amylase showed good stability with several solid commercial detergents tested, but it was less stable than crude protease. Two serine-proteases from Bacillus mojavensis A21 were highly stable in the presence of solid detergents at a concentration of $7 \mathrm{mg} \cdot \mathrm{mL}^{-1}$. The proteases exhibited higher

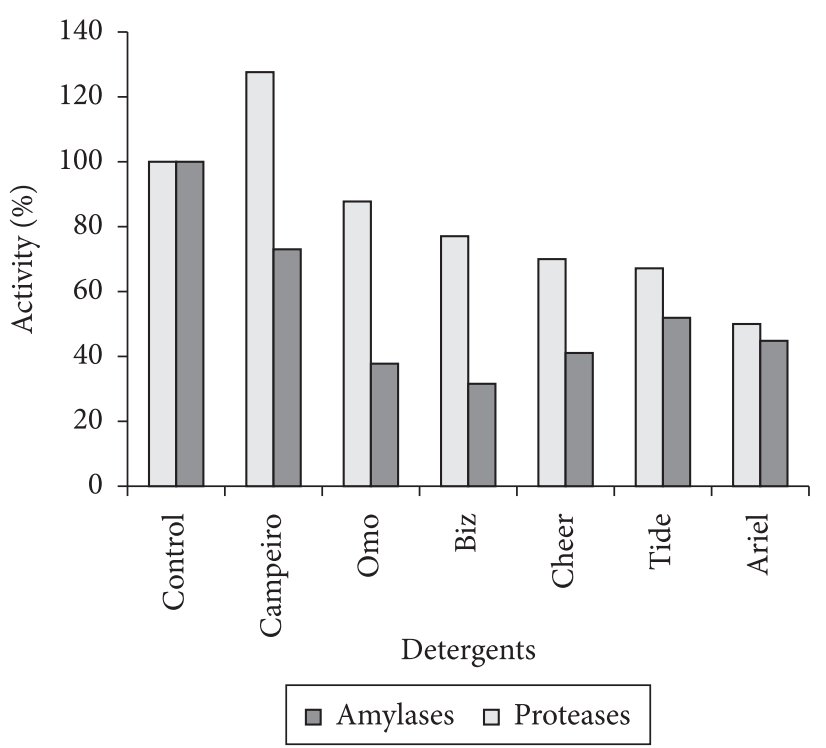

Figure 3. Effect of some detergents on the activities of a-amylase and protease from Bacillus sp. SMIA-2. The activity is expressed as a percentage of the activity level in the absence of detergents $\left(100 \%\right.$ of amylase activity $=406.9 \mathrm{U} \cdot \mathrm{mg}^{-1}$ protein; $100 \%$ of protease

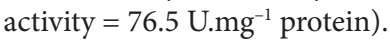

(a)

(b) stability in Axion (100\%) than in Ariel $^{\oplus}$, Dixan ${ }^{\circledast}$, and Nadhif However, BM1 and BM2 proteases were found to be less stable in the presence of New Det, retaining 79.4 and $87.5 \%$ of their initial activity, respectively (HADDAR et al., 2009). Compatibility studies of the purified protease from Bacillus circulans with detergents revealed that the activity of the enzyme decreased slightly (3-7\%) with an increase in incubation time indicating its suitability for commercial detergent formulations (RAO et al., 2009).

Bhosale et al. (1995) reported that highly alkaline protease detergents from Conidiobolus coronatus showed compatibility at $50{ }^{\circ} \mathrm{C}$ in the presence of $25 \mathrm{mM} \mathrm{CaCl}_{2}$ with a variety of commercial detergents. They reported that their enzyme preparation retained $16 \%$ activity in Revel ${ }^{\circ}, 11.4 \%$ in Ariel $^{\oplus}$, and $6.6 \%$ in Wheel ${ }^{\circledast}$.

Since the enzymes produced by Bacillus sp. SMIA-2 showed good compatibility with some commercial detergents tested, it was used as an additive in detergent to check the contribution of the enzyme to improve the washing performance of the detergent. Supplementation of Campeiro with the enzyme preparation improved its cleansing performance for removing egg yolk and tomato sauce stains (Figure 4). Similar results were noted by Hmidet et al. (2009), who found that a detergent supplemented with an enzymatic preparation from B. licheniformis $\mathrm{NH} 1$ containing both $\alpha$-amylase and proteases activities significantly improved the cleaning performance for removing blood, chocolate, and barbecue sauce stains.
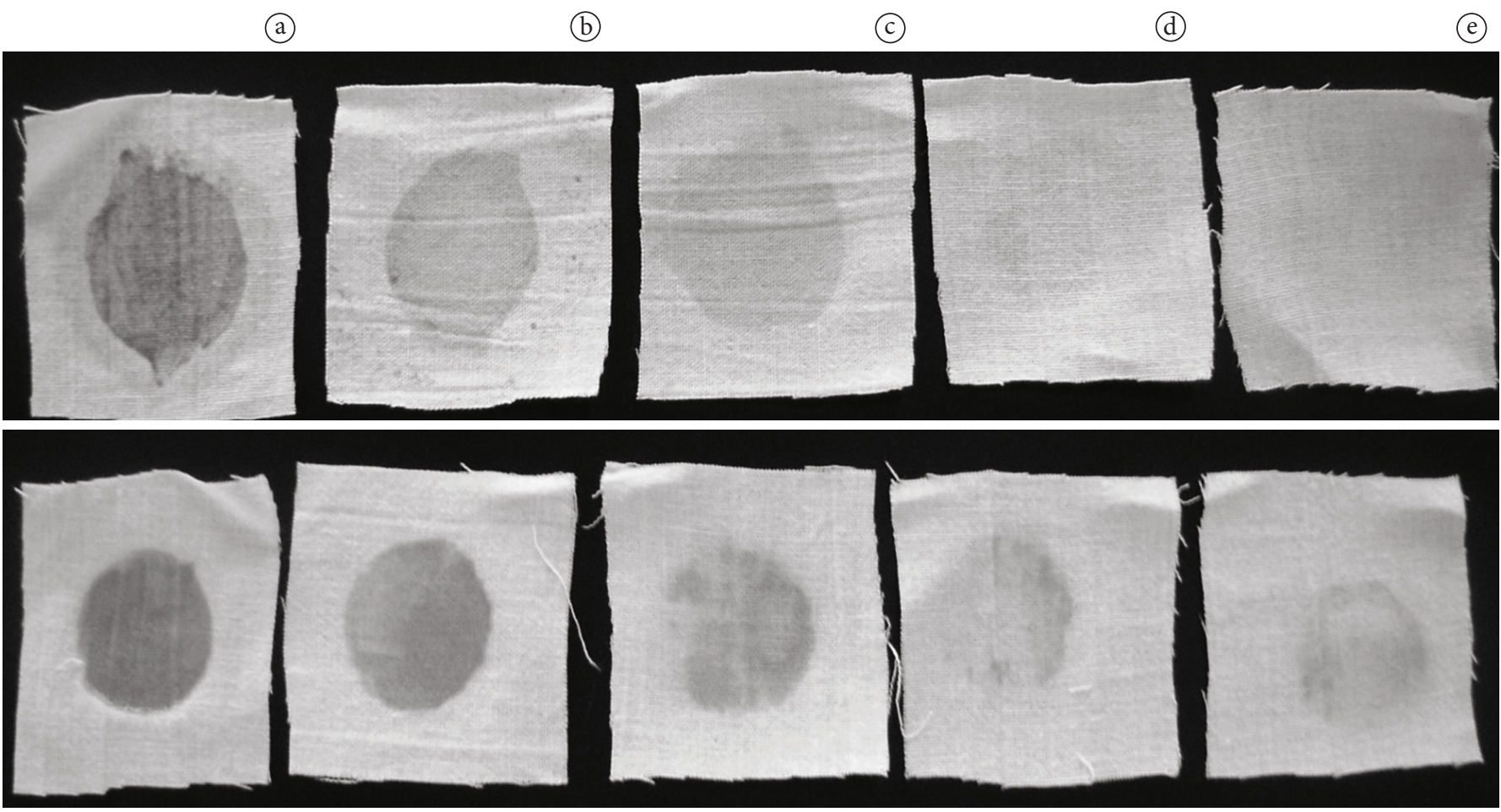

Figure 4. Washing performance of amylase and protease from Bacillus sp. SMIA-2 in the presence of detergent Campeiro .a) Cloth stained with egg yolk and tomato sauce (control); b) egg yolk and tomato sauce stained cloths washed with detergent only; c) egg yolk and tomato sauce stained cloth washed with detergent and $2 \mathrm{~mL}$ of crude enzymes; and d) egg yolk and tomato sauce stained cloth washed with detergent and $5 \mathrm{~mL}$ of crude enzymes. 


\section{Conclusion}

Bacillus sp. strain SMIA-2 simultaneously produces protease and $\alpha$-amylase when growing in a culture medium containing a low starch concentration, whey protein concentrate, and corn steep liquor. The enzyme activity levels were comparable with those reported when either of these enzymes was produced alone.

The enzymatic preparation containing both $\alpha$-amylase and protease activities produced simultaneously by Bacillus sp. SMIA-2 strain is capable of improving the cleansing performance for the removal of egg yolk and tomato sauce stains.

\section{Acknowledgements}

The authors are extremely grateful for the financial support provided by the FAPERJ (Fundação de Amparo a Pesquisa do Estado do Rio de Janeiro).

\section{References}

ABIDI, F.; LIMAN, F.; NEGIB, M. M. Production of alkaline proteases by Botrytis cinerea using economic raw materials: Assay as biodetergent. Process Biochemistry, vol. 43, n. 9, p. 12021208, 2008. http://dx.doi.org/10.1016/j.procbio.2008.06.018

AQUINO, A. C. M. M. et al. Studies on a thermostable $\alpha$-amylase from the thermophilic fungus Scytalidium thermophilum. Applied Microbiology and Biotechnology, vol. 61, n. 4, p. 323-328, 2003.

BANERJEE, U. C. et al. Thermostable alkaline protease from Bacillus brevis and its characterization as a laundry detergent additive. Process Biochemistry, vol. 35, n. 1-2, p. 213-219, 1999. http:// dx.doi.org/10.1016/S0032-9592(99)00053-9

BHOSALE, S. H. et al. Thermostability of high activity alkaline protease from Conidiobolus coronatus. Enzyme and Microbial Technology, vol. 17, n. 2, p. 136-139, 1995. http://dx.doi.org/10.1016/01410229(94)00045-S

CARVALHO, R. V. et al. Otimização das condições de cultivo para a produção de amilases pelo termofílico Bacillus sp. e hidrólise de amidos pela ação da enzima. Ciência e Tecnologia de Alimentos, vol. 28, n. 2, p. 380-386, 2008. http://dx.doi.org/10.1590/S010120612008000200017

DIAS, D. R. et al. Alkaline protease from Bacillus sp. isolated from coffee bean grown on cheese whey. World Journal of Microbiology and Biotechnology, vol. 24, n. 10, p. 2027-2034, 2008. http://dx.doi. org/10.1007/s11274-008-9706-6

GHORBEL, B.; SELLAMI-KAMOUN, A.; NASRI, M. Stability studies of protease from Bacillus cereus BG1. Enzyme and Microbial Technology, v. 32, n. 5, p. 513-518, 2003. http://dx.doi.org/10.1016/ S0141-0229(03)00004-8

GUPTA, R. et al. Microbial $\alpha$-amylases: a biotechnological perspective. Process Biochemistry, vol. 38, n. 11, p. 1599-1616, 2003. http:// dx.doi.org/10.1016/S0032-9592(03)00053-0

HADDAR, A. et al. Two detergent stable alkaline serine-proteases from Bacillus mojavensis A21: Purification, characterization and potential application as a laundry detergent additive. Bioresource Technology, vol. 100, n. 13, p. 3366-3373, 2009. PMid:19269812. http://dx.doi.org/10.1016/j.biortech.2009.01.061

HADJ-ALI, N. E. et al. Biochemical and molecular characterization of a detergent stable alkaline serine-protease from a newly isolated Bacillus licheniformis NH1. Enzyme and Microbial Technology, vol. 40, n. 4, p. 515-523, 2007. http://dx.doi.org/10.1016/j. enzmictec.2006.05.007

HMIDET, N. et al. Purification and biochemical characterization of a novel $\alpha$-amylase from Bacillus licheniformis NH1: Cloning, nucleotide sequence and expression of amyN gene in Escherichia coli. Process Biochemistry, vol. 43, n. 5, p. 499-510, 2008. http:// dx.doi.org/10.1016/j.procbio.2008.01.017

HMIDET, N. et al. Alkaline proteases and thermostable $\alpha$-amylase co-produced by Bacillus licheniformis NH1: Characterization and potential application as detergent additive. Biochemical Engineering Journal, vol. 47, n. 1-3, p. 71-79, 2009. http://dx.doi. org/10.1016/j.bej.2009.07.005

JANSSEN, P. H.; PEEK, K.; MORGAN, H. W. Effect of culture conditions on the production of a extracellular proteinase by Thermus sp. Rt41A. Applied Microbiology Biotechnology, vol. 41, n. 4, p. 400-406, 1994.

JOHNVESLY, B.; NAIK, G. R. Studies on production of thermostable alkaline protease from thermophilic and alkaliphilic Bacillus sp. JB-99 in a chemically defined medium. Process Biochemistry, vol. 37, n. 1, p. 139-144, 2001. http://dx.doi.org/10.1016/S00329592(01)00191-1

JOO, H. S.; CHANG, C. S. Production of protease from a new alkalophilic Bacillus sp. I-312 grow on soybean meal: optimization and some properties. Process Biochemistry, vol. 40, n. 3-4, p. 1263 1270, 2005. http://dx.doi.org/10.1016/j.procbio.2004.05.010

KIRAN, K. K.; CHANDRA, T. S. Production of surfactant and detergent-stable, halophilic, and alkalitolerant alpha-amylase by a moderately halophilic Bacillus sp. strain TSCVKK. Applied Microbiology and Biotechnology, vol. 77, n. 5, p. 1023-1031, 2008. PMid:17999060. http://dx.doi.org/10.1007/s00253-007-1250-z

MERHEB, C. W. et al. Partial characterization of protease from a thermophilic fungus, Thermoascus aurantiacus, and its hydrolytic activity on bovine casein. Food Chemistry, vol. 104, n. 1, p. 127131, 2007. http://dx.doi.org/10.1016/j.foodchem.2006.11.010

MILLER, G. L. Use of dinitrosalicylic acid reagent for determination of reducing sugars. Analytical Chemistry, vol. 31, p. 426-428, 1959. http://dx.doi.org/10.1021/ac60147a030

MING CHU, I.; LEE, C.; LI, T. S. Production and degradation of alkaline protease in batch cultures of Bacillus subtilis ATCC 144716. Enzyme Microbiology and Technology, vol. 14, n. 6, p. 755-761, 1992.

MITIDIERI, S. et al. Enzymatic detergent formulation containing amylase from Aspergillus niger: A comparative study with commercial detergent formulations. Bioresource Technology, vol. 97, p. 1217-1224, 2006. PMid:16112858. http://dx.doi. org/10.1016/j.biortech.2005.05.022

MUKHERJEE, A. K.; ADHIKARI, H.; RAI, S. K. Production of alkaline protease by a thermophilic Bacillus subtilis under solid-state fermentation (SSF) condition using Imperata cylindrical grass and potato peel as low-cost medium: Characterization and application of enzyme in detergent formulation. Biochemical Engineering Journal, vol. 39, n. 2, p. 353-361, 2008. http://dx.doi.org/10.1016/j. bej.2007.09.017

MUSSATO, S. I.; FERNANDES, M.; MILAGRES, A. M. F. Enzimas: Poderosa ferramenta na indústria. Ciência Hoje, vol. 41, p. 28 33, 2007.

NASCIMENTO, W. C. A.; MARTINS, M. L. L. Production and properties of an extracellular protease from thermophilic Bacillus sp. Brazilian Journal of Microbiology, vol. 35, p. 91-96, 2004. http:// dx.doi.org/10.1590/S1517-83822004000100015 
NIELSEN, J. E.; BORCHERT, T. V. Protein engineering of bacterial a-amylases. Biochemica et Biophysica Acta, vol. 1543, p. 253274, 2000. http://dx.doi.org/10.1016/S0167-4838(00)00240-5

OLIVEIRA, A. N. et al. Enzimas hidrolíticas extracelulares de isolados de rizóbia nativos da Amazônia Central, Amazonas, Brasil. Ciência e Tecnologia de Alimentos, vol. 26, n. 1, p. 204-210, 2006. http:// dx.doi.org/10.1590/S0101-20612006000100032

PELIZER, L. H.; PONTIERI, M. H.; MORAES, I. O. Utilização de resíduos agro-industriais em processos biotecnológicos com perspectiva de redução do impacto ambiental. Journal of Technology Management \& Innovation, vol. 2, n. 1, p. 118-127, 2007.

PETERSON, G. L. A simplification of the protein assay method of Lowry et al. which is more generally applicable. Analytical Biochemistry, vol. 83, n. 2, p. 346-356, 1977. http://dx.doi. org/10.1016/0003-2697(77)90043-4

PHADATARE, S. U.; DESHPANDE, V. V.; SRINIVASAN, M. C. High activity alkaline protease from Conidiobolus coronatus (NCL 86. 8. 20): Enzyme production and compatibility with commercial detergents. Enzyme and Microbial Technology, vol. 15, n. 1, p. 72-76, 1993. http://dx.doi.org/10.1016/01410229(93)90119-M

RAO, C. S. et al. Characterization on thermo- and detergent stable serine protease from isolated Bacillus circulans and evaluation of eco-friendly applications. Process Biochemistry, vol. 44, n. 3, p. 262-268, 2009. http://dx.doi.org/10.1016/j.procbio.2008.10.022

RAO, M. B. et al. Molecular and biotechnological aspects of microbial proteases. Microbiology and Molecular Biology Reviews, vol. 62, n. 3, p. 597-635, 1998. PMid:9729602. PMCid:98927.

RIVAS, B.; MOLDES, A. B.; DOMINGUEZ, J. C. Development of culture media containing spent yeast cells of Debaryomyces hansenii and corn steep liquor for lactic acid production with Lactobacillus rhamnosus. International Journal of Food Microbiology, vol. 97, n. 1, p. 93-98, 2004. PMid:15527923. http://dx.doi.org/10.1016/j. ijfoodmicro.2004.05.006

SAJEDI, R. H. et al. A Ca-independent $\alpha$-amylase that is active and stable at low pH from the Bacillus sp. KR-8104. Enzyme and Microbial Technology, vol. 36, n. 5-6, p. 666-671, 2005. http:// dx.doi.org/10.1016/j.enzmictec.2004.11.003

SAXENA, R. K. et al. A highly thermostable and alkaline amylase from a Bacillus sp. PN5. Bioresource Technology, vol. 98, n. 2, p. 260-265, 2007. PMid:16524725. http://dx.doi.org/10.1016/j. biortech.2006.01.016

SCHALLMEY, M.; SINGH, A.; WARD, O. P. Developments in the use of Bacillus species for industrial production. Canadian Journal Microbiology, vol. 50, n. 1, p. 1-17, 2004. PMid:15052317. http:// dx.doi.org/10.1139/w03-076

SELLAMI-KAMOUN, A. et al. Stability of thermostable alkaline protease from Bacillus licheniformis RP1 in commercial solid laundry detergent formulations. Microbiological Research, vol. 163, n. 3, p. 299-306, 2008. PMid:16872818. http://dx.doi. org/10.1016/j.micres.2006.06.001

SOUZA, A. N.; MARTINS, M. L. L. Isolation, properties and kinetics of growth of a thermophilic Bacillus. Brazilian Journal of Microbiology, vol. 32, n. 4, p. 271-275, 2001. http://dx.doi. org/10.1590/S1517-83822001000400003

van DER MAAREL, M. J. E. C. et al. Properties and applications of starch-converting enzymes of the $\alpha$-amylase family. Journal of Biotechnology, vol. 94, n. 2, p. 137-155, 2002. http://dx.doi. org/10.1016/S0168-1656(01)00407-2 


\section{Errata/Erratum}

CORREA, T. L. R. et al. Simultaneous $\alpha$-amylase and protease production by the soil bacterium Bacillus sp. SMIA- 2 under submerged culture using whey protein concentrate and corn steep liquor: compatibility of enzymes with commercial detergents. Ciência e Tecnologia de Alimentos, v. 31, n. 4, p. 843-848, 2011. http://dx.doi.org/10.1590/S0101-20612011000400003

Na página 845, as legendas das Figuras 1 e 2 foram invertidas:

Onde lê-se: DO600nm (०); pH (-); Amylase activity $(\Delta)$; Protease activity ( $(\boldsymbol{\Delta})$.

Lê-se: DO600nm (०); pH (•); Amylase activity ( $\Delta)$; Protease activity $(\Delta)$.

Na página 846, a legenda da Figura 3 foi invertida:

Onde lê-se: $\square$ Amylases $\square$ Proteases

Lê-se: $\square$ Amylases $\square$ Proteases

Na página 846, faltaram dados na legenda da Figura 4:

Onde lê-se: Figure 4. Washing performance of amylase and protease from Bacillus sp. SMIA-2 in the presence of detergent Campeiro ${ }^{\circ}$. a) Cloth stained with egg yolk and tomato sauce (control); b) egg yolk and tomato sauce stained cloths washed with detergent only; c) egg yolk and tomato sauce stained cloth washed with detergent and $2 \mathrm{~mL}$ of crude enzymes; and d) egg yolk and tomato sauce stained cloth washed with detergent and $5 \mathrm{~mL}$ of crude enzymes.

Lê-se: Figura 4. Washing performance of amylase and protease from Bacillus sp. SMIA-2 in the presence of detergent Campeiro ${ }^{\circ}$. a) Cloth stained with egg yolk and tomato sauce (control); b) egg yolk and tomato sauce stained cloths washed with distilled water only; c) egg yolk and tomato sauce stained cloths washed with detergent only; d) egg yolk and tomato sauce stained cloth washed with detergent and $2 \mathrm{~mL}$ of crude enzymes; and e) egg yolk and tomato sauce stained cloth washed with detergent and $5 \mathrm{~mL}$ of crude enzymes. 